\title{
ANTIBACTERIAL RESISTANCE PATTERN OF PSEUDOMONAS AERUGINOSA CO-ISOLATED WITH OTHER AEROBIC BACTERIA FROM BURN WOUNDS IN TERTIARY CARE HOSPITAL
}

Kalpana Sadawarte ${ }^{1}$, Sneha Dadarya ${ }^{2}$, Tukaram Prabhu $\mathrm{K}^{3}$

\section{HOW TO CITE THIS ARTICLE:}

Kalpana Sadawarte, Sneha Dadarya, Tukaram Prabhu K."Antibacterial Resistance Pattern of Pseudomonas Aeruginosa Co-Isolated with other Aerobic Bacteria from Burn Wounds in Tertiary Care Hospital". Journal of Evolution of Medical and Dental Sciences 2014; Vol. 3, Issue 02, January 13; Page: 464-468, DOI:10.14260/jemds/2014/1850

ABSTRACT:The antibacterial resistance pattern of 118 isolates from burn wounds in patients with thermal burns showing growth of Pseudomonas aeruginosa mixed with other aerobic bacteria over a period of two years (January 2009-December2010) were studied. Pseudomonas aeruginosa was found to be mixed with Klebsiella pneumoniae 63 (53.38\%) the most followed by Escherichia coli 27 $(22.88 \%)$ and other aerobic isolates. Pseudomonas aeruginosa was found to be highly resistant to Ceftazidime (72.88\%) and least to Imipenem (9.32\%). Klebsiella pneumoniae was found to be most resistant to Ampicillin (100\%) and least to Amikacin (23.72\%). Antibiotic susceptibility testing was performed for the other isolates as well.

KEY WORDS: Burn Wound infection, Pseudomonas aeruginosa, Antibiotic resistance.

INTRODUCTION: The colonization and infection in burn victims is a problem in their management as burn wounds are susceptible to infection ${ }^{1}$. Major cause behind mortality and morbidity in burn patients who are hospitalized is infection ${ }^{2}$.The determination of antimicrobial sensitivity pattern, changes in dominant microbial flora and burn wound microbial colonization is very important ${ }^{3}$.Due to the longer hospital stay, larger suitable burn site and rich source for bacterial multiplication than surgical wounds helps in survival of organisms ${ }^{4}$. There is a lot of change in the pattern of bacterial flora with respect to the hospital environment and during healing period in wound ${ }^{5}$. The antibiotic susceptibility pattern helps in selection of proper empirical treatment in a hospital beforehand. In the present retrospective study an attempt has been made to analyze and compile the pattern of bacterial infection in the burn wounds and their antibiotic susceptibility pattern to benefit the patient.

MATERIAL AND METHODS: This retrospective study was conducted between January 2009 to December 2010 in a 750-bedded tertiary care hospital. 118 isolates which showed growth of Pseudomonas aeruginosa mixed with other aerobic isolates were included in the present study. The ones without the growth of Pseudomonas spp were excluded.

Burn wound swabs/specimens/pus were collected and sent to the laboratory following standard precautions and protocols for the processing. The samples were inoculated on blood agar, MacConkey's agar and chocolate agar, incubated at $37^{\circ} \mathrm{C}$ overnight aerobically ${ }^{6}$.

Over the study period, 118 non-duplicate consecutive P. aeruginosa isolated from the burn specimens were identified by standard bacteriological methods 7 .

Antibiotic susceptibility testing was determined by disc diffusion method using MuellerHinton agar plates following standard $\operatorname{method}^{7,8}$. The isolates were identified by culture, staining 
and biochemical tests including oxidase, lactose and maltose fermentation, catalase and their antibiotic sensitivity determined using Kirby Bauer disc diffusion technique.7, 8, 9

Following antibiotics were used as per Clinical and Laboratory Standard Institute (CLSI) guidelines ${ }^{9}$

For Pseudomonas aeruginosa - piperacillin [100mcg], piperacillin-tazobactum [100/10mcg], gentamicin [10 mcg], tobramycin [10 mcg], amikacin [30 mcg], netilmicin [30 mcg], ceftazidime [30 mcg], imipenem [10 mcg], cefepime [30 mcg], aztreonam [30mcg], ciprofloxacin [5mcg] and cefotaxime [30mcg].

For Gram negative isolates gentamicin [10 $\mathrm{mcg}$ ], amikacin [30 $\mathrm{mcg}$ ], ceftazidime [30mcg], imipenem [10 mcg], ciprofloxacin [5mcg], ampicillin [10 mcg], amoxy-clav [20/10 mcg], cefotaxime $[30 \mathrm{mcg}]$, cotrimoxazole $[1.25 / 23.75 \mathrm{mcg}]$, piperacillin $[100 \mathrm{mcg}]$ and piperacillin-tazobactum [100/10mcg]

For Staphylococcus aureus cephoxitin [30mcg], erythromycin [15mcg], penicillin [10U], ciprofloxacin [5mcg], vancomycin [30mcg] ampicillin [10mcg], amoxy-clav [20/10mcg], cotrimoxazole [1.25/23.75mcg], cephoxitin [30 mcg] and cephalothin [30 mcg].

RESULTS: In the present study, during a period of two years 118 specimen which showed multiple isolates along with Pseudomonas aeruginosa were included in this study. Along with Pseudomonas aeruginosa the other aerobic isolates included 63 (53.38\%) Klebsiella peumoniae specieswhich was found to be most common followed by E coli 27 (22.88\%), Staphylococcus aureus 20 (16.94\%), Proteus vulgaris 05 (4.23\%) and Acinetobacter species 03 (2.54\%). [Table I]

Most of the Pseudomonas aeruginosaisolates were resistant to cephalosporins (ceftazidime 72.88\%, cefotaxime-71.18\%, cefepime-68.64\%) and least to Imipenem (9.32\%). [Table II]

Staphylococcus aureus was found to be most resistant to ampicillin (85\%) followed by penicillin (75\%) and cephalothin (70\%). Cephoxitin was used to test for methicillin resistance and $60 \%$ of the isolates were resistant and none of the isolates were resistant to vancomycin. [Table III]

The Gram negative aerobic isolates found to be most resistant to ampicillin $100 \%, 88.88 \%$, $80 \%$ for Klebsiella pneumoniae, E coli and P vulgaris respectively.

Klebsiella species were found to be less resistant to Amikacin (63.49\%) and Ciprofloxacin $(42.85 \%)$.

Similarly E. coli was found to be less resistant to amikacin $62.96 \%$ and ciprofloxacin $59.25 \%$, whereas $20 \%$ of Proteus vulgaris were resistant to amikacin and ciprofloxacin.

Piperacillin-tazobactum, Amikacin, Imipenem (all 66.66\%) was determined to be more effective against Acinetobacter species. All the isolates of Acinetobacter species showed resistance to cefotaxime and cotrimoxazole. [Table IV]

DISCUSSION: The aerobic isolates included in this study were Pseudomonas aeruginosa co-isolated with various aerobic gram positive and gram negative isolates of which Klebsiella pneumonia 63 (53.38\%) was found to be most common followed by E. coli 27 (22.88\%), Staphylococcus aureus 20 (16.94\%), Proteus vulgaris 05 (4.23\%) and Acinetobacter species 03 (2.54\%).

Patients in age group of 15-35 years were predominant in the study, most of them were females. In the present study, all the Pseudomonas aeruginosa were co-isolated with other aerobic bacterial growth from burn cases as mentioned elsewhere ${ }^{11}$. Klebsiella pneumoniae is predominant organism along with Pseudomonas aeruginosa in the present study in contrast to some other studies 
which reports Staphylococcus aureus as predominant isolate ${ }^{11,12}$.The moist environment (open wounds and use of antiseptics) helps Pseudomonas to survive which might be a reason behind their predominance in burn wards ${ }^{13}$.

CONCLUSION: It was observed that Pseudomonas aeruginosa along with Klebsiella pneumoniaewas the commonest isolate among the mixed bacterial isolate in burn wound cases and it showed multidrug resistance. In conclusion, present observations seem to be helpful in providing useful guidelines for choosing effective therapy against isolates from burn patients and decrease mortality and morbidity. Also to be taken into consideration is the fact the most of these infections involve more than one bacterial species.In-vitro antibiotic testing of burn wound isolates prior its use is helpful in management of bacterial infection and prevents development of multidrug resistance in pathogens.

\section{REFERENCES:}

1. Macedo JLS, Santos JB. Bacterial and fungal colonization of burn wounds. Mem Inst Oswaldo Cruz 2005; 100: 535-539.

2. Mc Manus A.T., Mason A.D.jr, McManus W.F., Pruitt B.A, Jr: A decade of reduced Gram -negative infections and mortality improved isolation of burned patients. Arch.Surg., 1994; 129: 13061309.

3. Coker A0. Bacteriology of burns at the Lagos university teaching hospital. West African Journal of Medicine 1983; 2:53-258

4. Agnihotri N, Gupta V, Joshi RM., Aerobic bacterial isolate from burn wound infections and their antibiograms - a five - year study. Burns 2004; 30: 241-243.

5. Kumar V., Bhatnagar SK., Singh AK., Kumar S., Mishra RK. Burn Wound Infection: A study of 50 cases with special reference to antibiotic resistance. Indian Journal of Bio Research 2001; 46: 66-69.

6. Forbes BA, Sahm DF, Weissfeld AS. Bailey and Scott's Diagnostic Microbiology. 11th edition, Mosby, 2002

7. Gillgan PH. Pseudomonas aeruginosa and Burkholderia. In: Murrey PR, Baron EJ, Pfaler AA, et al, eds. Manual of Clinical Microbiology, $6^{\text {th }}$ Sub ed. Pp. 509-19, Washington DC, American Society for Microbiology, 1995.

8. Bauer AN, Kirby WMM, Sherris J, et al. Antibiotic susceptibility testing by a standardized single disk method. Am J Clin Pathol, 1966; 45: 493-6.

9. Clinical and Laboratory Standard Institute (CLSI) guidelines. Performance standards for antimicrobial susceptibility testing, M-100-S21, Vol 31 No.1, 2011.

10. Zorgani A., Zaidi M., Ranka R., Shahen A.:The pattern and outcome of septicaemia in a burns intensive care unit.Ann.Burns Diasters, 2002;15: 179-182.

11. Donati I, Scammazo F, Gervasoni M, Magliano A, Stankov B, Fraschini F. Infection and antibiotic therapy in 4000 burned patients treated in Milan, Italy, between 1976 and 1988. Burns 1993; 19: $345-348$

12. Revathi G, Puri J, Jain BK. Bacteriology of burns. Burns, 1998; 24: 347-349.

13. Atoyebi OA, Sowemimo GOA, Odugbemi T. Bacterial flora of burn wounds in Lagos, Nigeria: a prospective study. Burns 1992; 18: 448-451. 
ORIGINAL ARTICLE

\begin{tabular}{|c|l|c|c|}
\hline S.No & \multicolumn{1}{|c|}{ Organism } & No. $(\mathrm{n}=118)$ & Percentage \\
\hline 1. & Staphylococcus aureus & 20 & $16.94 \%$ \\
\hline 2. & Klebsiella pneumoniae & 63 & $53.38 \%$ \\
\hline 3. & Escherichia coli & 27 & $22.88 \%$ \\
\hline 4. & Proteus vulgaris & 05 & $4.23 \%$ \\
\hline 5. & Acinetobacter species & 03 & $2.54 \%$ \\
\hline & Total & 118 & \\
\hline
\end{tabular}

Table 1: Number of Isolates mixed with Pseudomonas $(n=118)$

\begin{tabular}{|l|c|c|}
\hline \multicolumn{1}{|c|}{ Antibiotic } & No. $(\mathrm{n}=118)$ & Percentage \\
\hline Piperacillin & 55 & $46.61 \%$ \\
\hline Piperacillin tazobactum & 38 & $32.20 \%$ \\
\hline Ceftazidime & 86 & $72.88 \%$ \\
\hline Ciprofloxacin & 52 & $44.06 \%$ \\
\hline Imipenem & 11 & $9.32 \%$ \\
\hline Cefotaxime & 84 & $71.18 \%$ \\
\hline Gentamicin & 49 & $41.52 \%$ \\
\hline Amikacin & 28 & $23.72 \%$ \\
\hline Tobramycin & 60 & $50.84 \%$ \\
\hline Netilmicin & 54 & $45.76 \%$ \\
\hline Aztreonam & 39 & $33.05 \%$ \\
\hline Cefepime & 81 & $68.64 \%$ \\
\hline
\end{tabular}

Table 2: Antibiotic resistance pattern of Pseudomonas species

\begin{tabular}{|l|l|}
\hline Antibiotic & $\begin{array}{l}\text { No. } \\
\text { (Percentage) }\end{array}$ \\
\hline Penicillin & $15(75 \%)$ \\
\hline Ampicillin & $17(85 \%)$ \\
\hline Erythromycin & $10(50 \%)$ \\
\hline Cephalothin & $14(70 \%)$ \\
\hline Cephoxitin & $12(60 \%)$ \\
\hline Vancomycin & $00(0 \%)$ \\
\hline Ciprofloxacin & $10(50 \%)$ \\
\hline Amoxy- Clav & $09(45 \%)$ \\
\hline Cotrimoxazole & $13(65 \%)$ \\
\hline \multicolumn{2}{|c|}{ Table 3: Antimicrobial resistance } \\
pattern of Staphylococcus aureus \\
\hline
\end{tabular}




\begin{tabular}{|c|c|c|c|c|c|c|c|c|}
\hline Antibiotic & \multicolumn{2}{|c|}{$\begin{array}{c}\text { Klebsiella } \\
\text { pneumoniae }\end{array}$} & \multicolumn{2}{|c|}{ E coli } & \multicolumn{2}{c|}{$\begin{array}{c}\text { Proteus } \\
\text { vulgaris }\end{array}$} & \multicolumn{2}{|c|}{ Acinetobacter spp } \\
\hline $\begin{array}{c}\text { No. } \\
(\mathrm{n}=63)\end{array}$ & $\begin{array}{c}\text { Percent } \\
\text { of } \\
\text { resistant } \\
\text { strains }\end{array}$ & $\begin{array}{c}\text { No. } \\
(\mathrm{n}=27)\end{array}$ & $\begin{array}{c}\text { Percent } \\
\text { of } \\
\text { resistant } \\
\text { strains }\end{array}$ & $\begin{array}{c}\text { No. } \\
(\mathrm{n=05})\end{array}$ & $\begin{array}{c}\text { Percent } \\
\text { of } \\
\text { resistant } \\
\text { strains }\end{array}$ & $\begin{array}{c}\text { No. } \\
(\mathrm{n}=03)\end{array}$ & $\begin{array}{c}\text { Percent } \\
\text { of } \\
\text { resistant } \\
\text { strains }\end{array}$ \\
\hline Ampicillin & 63 & $100 \%$ & 24 & $88.88 \%$ & 4 & $80 \%$ & -- & -- \\
\hline Amox-clav & 53 & $84.12 \%$ & 21 & $77.77 \%$ & 3 & $60 \%$ & -- & -- \\
\hline Cotrimoxazole & 53 & $84.12 \%$ & 21 & $77.77 \%$ & 4 & $80 \%$ & 3 & $100 \%$ \\
\hline Ciprofloxacin & 27 & $42.85 \%$ & 16 & $59.25 \%$ & 1 & $20 \%$ & 2 & $66.66 \%$ \\
\hline Cefotaxime & 50 & $79.36 \%$ & 22 & $81.48 \%$ & 2 & $40 \%$ & 3 & $100 \%$ \\
\hline Gentamicin & 45 & $71.42 \%$ & 19 & $70.37 \%$ & 3 & $60 \%$ & 2 & $66.66 \%$ \\
\hline Amikacin & 40 & $63.49 \%$ & 17 & $62.96 \%$ & 1 & $20 \%$ & 1 & $33.33 \%$ \\
\hline Piperacillin & -- & -- & -- & -- & -- & -- & 2 & $66.66 \%$ \\
\hline $\begin{array}{c}\text { Piperacillin } \\
\text { tazobactum }\end{array}$ & -- & -- & -- & -- & -- & -- & 1 & $33.33 \%$ \\
\hline Ceftazidime & -- & -- & -- & -- & -- & -- & 2 & $66.66 \%$ \\
\hline Imipenem & -- & -- & -- & -- & -- & -- & 1 & $33.33 \%$ \\
\hline
\end{tabular}

\section{AUTHORS:}

1. Kalpana Sadawarte

2. Sneha Dadarya

3. Tukaram Prabhu K.

\section{PARTICULARS OF CONTRIBUTORS:}

1. Professor, Department of Microbiology, People's College of Medical Sciences \& Research Centre, Bhopal.

2. Tutor, Department of Microbiology, People's College of Medical Sciences \& Research Centre, Bhopal.

3. Assistant Professor, Department of Microbiology, People's College of Medical Sciences \& Research Centre, Bhopal.

\section{NAME ADDRESS EMAIL ID OF THE CORRESPONDING AUTHOR:}

Dr. Kalpana Sadawarte,

Professor,

Department of Microbiology,

People's College of Medical Sciences \& Research

Centre, By-Pass Road, Bhanpur,

Bhopal - 462037 (M.P.)

Email- drkalpanasadawarte@gmail.com

Date of Submission: 09/12/2013.

Date of Peer Review: 10/12/2013.

Date of Acceptance: 23/12/2013.

Date of Publishing: 10/01/2014 